\title{
Trace fossils in a Lower Palaeozoic submarine canyon sequence - the Siegas Formation of northwestern New Brunswick, Canada
}

\author{
R.K. Pickerizl, Department of Geology \\ University of New Brunswick, Fredericton, New Brunswick, Canada E3B $5 A 3$
}

\begin{abstract}
The Slegas Formation (S1lurian-early Llandovery) of northwestern New Brunawick represents, In part, an ancient example of a submarine canyon oequence, erosive into and partially coeval with the Carys Milla Formation of late Ordoviclan-middle Llandovery age. The canyon succession contains a moderately diverse fchnofauna cons1sting of Buthotrephis, Chondrites, Cochlichnus anguineus, Dipliahnites, Fucusopois, Gordia arcucta, Cordia, Gyrochorte, Helminthoida labyminthica, Helminthopsis of. abeli, Neonereites biserialis, Neonereites uniserialis, Planolites beverieyeneis, Protopaleodictyon, Scalarituba miseouriensis and Skolithos. These trace fossils are described in detall.

Contrary to previous predictions that dwelling burrows and associated traces would predominate in submarine canyon sequences, the Slegas Formation contalna traces produced esentially by vagile sediment eaters. This is perhaps best explained by the abence within the canyon, at least for the majority of time, of sufficlently strong bottom currents, which precluded inhabitation by an active and abundant suspension feeding population. Instead, the sediments probably contained sufficlently abundant organic detritus to support an active population of infaunal sediment feeding organisms.
\end{abstract}

\begin{abstract}
Située au nord-ouest du Nouveau-Brunswick, la formation de Siegas (S1lurien - Llandovery inférieur) représente, en partie, un exemple ancien de séquence de canyon 6ous-marin; elle recoupe la formation de Carý Mills (ordoviclen supérleut - Llandovery moyen) et eet en partie contemporalne à cette derntère. On rencontre dans la séquence une 1chnofaune modérément diverse comprennant Buthotrephis, Chondrites, Cochlichnus conguineus, Diplichnites, Fucusopsis, Gordia arcuata, Gordia, Gyrochorte, Heiminthoida Labyrinthica, Helminthopsis of. abeli, Neonereites biserialis, Neonereites uniserialis, Planolites beverleyensis, Protopaleodictyon, Sealorituba missouriensis et Skolithos. Ces traces fosslles sont décrites en détall.

Selon les prédictions antérieures, les terriers d'habitation et les traces connexes devraient prédominer dans les séquences de canyon sous-marin ma1s contrairement à cec1, la formation siegas contient plutôt des traces produltes essentiellement par des ingesteurs de sédiment vagiles. Au mieux, ceci pourralt s'expliquer par l'exclusion d'une population active et abondante d'animaux filtreurs, due à l'absence dans le canyon, au moins la plupart du temps, de courants de fond signiflcatifs. Au lieu de cela, les sédiments devalent conten1r suffisament de détritus organiques pour accomoder une population active d'organismes endoblontes IImivores.
\end{abstract}

[Tradult par le journal]

\section{INTRODUCTION}

Oceanographic research has demonstrated that penetration and stirring of sediment by benthic and other organisms is a common phenomenon in modern submarine canyons (e.g. Shepard and Dill 1966, Trumbull and McCamis 1967, Dillon and Zimmerman 1970, Heezen and Hollister 1971, scott and Birdsall 1978, Valentine et $\alpha$. 1980). Yet little research has thus far been undertaken on the nature of trace fossils and trace fossil assemblages in ancient submarine canyon sequences. In part this has arisen from the inherent difficulties of recognizing ancient submarine canyons but also by research workers placing more emphasis on their detailed facies associations and sediment emplacement mechanisms (e.g. Stanley and Bertrand 1979).

One exception is the recent documentation by Hayward (1976) of the trace fossils from a Miocene submarine canyon sequence in New Zealand. Hayward described Tigizlites, Scalarituba, Planolites and branching "Planolites"*, from the unconsolidated sediments of the canyon floor and Tigillites, Rhizocorallium and several varieties of horizontal and inclined branching burrows from the semiconsolidated but unlithified canyon walls. More recently crimes (1977) produced a table which, in part, recorded both the known and anticipated ichnofaunas of ancient submarine canyon sequences. This

* Strictly speaking branching forms are not available for the ichnogenus

Planolites (Häntzsche1 1975).

MARITIME SEDIMENTS AND ATLANTIC GEOLOGY

$17,36-58(1981)$ 
paper is therefore intended to document the trace fossils occurring in an ancient submarine canyon sequence and to add to the data presented by crimes ( $i b i d$.) so that eventually more realistic and predictable models will be realized. The definition of a submarine canyon adopted here is the same as that proposed by Heezen and Hollister (1971) i.e. "any persistent valley found on the continental margin regardjess of shape or size", or alternatively but less specifically, following Bates and Jackson (1980), a "general term for all valleys of the deep-sea floor".

\section{STRATIGRAPHIC BACKGROUND}

Strata under consideration in this paper are referred to as the Siegas Formation of HamiltonSmith (1970), which crops out in the Siegas area of northwestern New Brunswick (Fig. 1). The formation occurs within a (now) relatively narrow northeast-southwest elongate trough which extends from Gaspé through New Brunswick and into Maine and tẹmed the Central

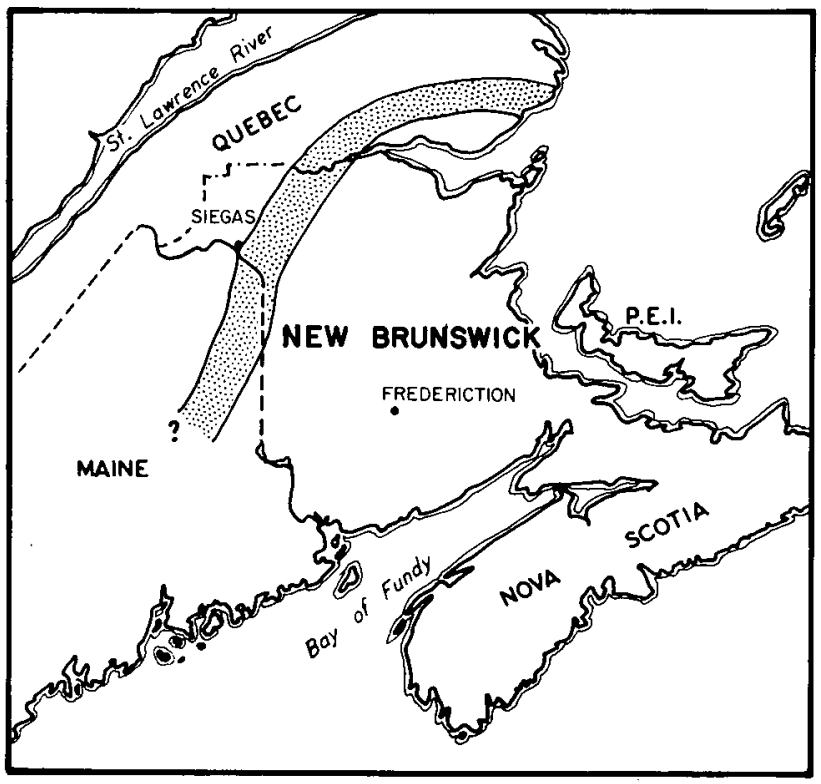

Fig. 1 - The Aroostook-Matapedia Carbonate Belt (stippled) of Gaspé, northwest New Brunswick and northeast Maine.
Clastic Belt and/or AroostoockMatapedia Carbonate Belt by Ayrton et al. (1969). In terms of recently proposed plate tectonic models (Rast and Stringer 1980) the trough represents a remnant of the Lower Palaeozoic Iapetus Ocean.

The Siegas Formation is of restricted areal extent, persisting some $11 \mathrm{~km}$ to the north and north west of Siegas and $9.5 \mathrm{~km}$ to the south and southeast. In thickness it ranges from between c. 107-244 $\mathrm{m}$ in the Siegas area to zero at its northwestern and southeastern limits where it passes into coeval strata of the Carys Mills Formation (Hamilton-Smith 1971a). Both this latter formation and the Siegas Formation are conformably overlain by the Perham Group of post-early Llandovery to early Ludlow age (Hamilton-Smith 1970, Roy and Mencher 1976).

Fragmentary brachiopod faunas recognized by Ayrton et al. (1969) have indicated an early Llandovery age for the Siegas Formation.

\section{SEDIMENTOLOGY AND}

\section{DEPOSITIONAL ENVIRONMENT}

The sedimentology and depositional environment of the siegas Formation has been studied in detail and succinctly described in a series of papers by HamiltonSmith (1971a, 1971b, 1980). This section presented below therefore summarizes the major conclusions of Hamilton-Smith together with observations made by the present author. In view of the purpose of this paper, only a brief summation will be presented here, and the interested reader is referred to the above papers for a more detailed appraisal and for detailed geological maps of the area.

Detailed mapping of the Siegas area by Hamilton-Smith (1970) de- 
monstrated that in the north and northwestern part of the area the Siegas Formation was erosive into the underlying Carys Mills Formation. The depth of erosion was estimated to be in the order of between 25-50 m, i.e. comparable to known erosional depths of many present day small submarine canyon systems (see Shepard and Dill 1966, Whitaker 1976, etc.), and much larger than reported modern and ancient inner and middle fan channels (see Walker and Mutti 1973). This, combined with a detailed sedimentological appraisal, led Hamilton-Smith (1971b) to suggest that in the north and northwestern part of the area, the Siegas Formation represented a submarine canyon-fill. Indeed, the absence of thinning and fining upward sequences and thickening and coarsening upward sequences, characteristic of mid-fan and suprafan lobes respectively, combined with the nature of the sediments, do suggest deposition in an extremely 'proximal' environment comparable to many modernday and ancient submarine canyon systems (see Middleton and Bouma 1975, Whitaker 1976, Stanley and Kelling 1978 and Doyle and Pilkey 1979).

Although it is difficult to generalize on the nature of these sediments, particularly as there are demonstrable proximal-distal relationships across the entire studied area, the canyon-fill strata or the 'Iithic wacke facies' of Hamilton-Smith (1970) exhibit the following characteristics.

(i) Organized and disorganized matrix-supported conglomerates up to $8.5 \mathrm{~m}$ in thickness. Clasts are dominantly of limestone but also include slate, chert and mafic volcanics, and the matrix is generally mud and/or fine silt. Many of the organized conglomerates are erosive (a maximum of $2 \mathrm{~m}$ having been observed), normally graded and/or imbricated and contain clasts up to $80 \mathrm{~cm}$ in diameter. In others, the preferred clast orientation is essentially parallel to bedding, similar to those recently described by Keith and Friedman (1977) from canyon and slope channelized and, or, sheet flow deposits from the Cambrian of New York and Vermont.

The graded and imbricated varieties are interpreted as the product of deposition from turbulent flows (turbidity currents) whereas the other varieties were probably produced by various forms of mass flow, such as debris flow or from incoherent slumping to a complex sliding of relatively coherent lenticules one over another.with most of the shear stress concentrated near lenticule margins Hamilton-Smith 1980). Conglomerates resembling those described briefly here have been mentioned in the literature quite extensively (see Walker and Mutti 1973 and Walker 1975 for a review) and are considered by the majority of authors to be characteristic of submarine canyon or inner fan channel deposits. This lithofacies association constitutes some $13 \%$ of the succession (Hamilton-Smith 1970).

(ii) Medium - coarse sandstones up to $2.75 \mathrm{~m}$ in thickness and dominated by varieties exhibiting complete and/or partial Bouma sequences. These sandstones exhibit a variety of sole features including ripples, flutes, tools, loads and gutter casts and are typically graded. Convolute lamination is also commonly developed. They are clearly a product of deposition by turbidity currents in a 'proximal' regime. Other sandstones are massive, internally structureless, and contain outsize pebble and cobble carbonate clasts 
randomly distributed throughout. Since there are no fluid escape structures the origin of these beds may possibly be explained by several processes: (i) deposition under upper flow regime, (ii) shearing by loosely compacted sediment, (iii) deposition by a rapidly decelerating current that failed to produce an equilibrium bedform (cf. McCabe 1978), (iv) fluidized sediment flow, (v) late stage fluidization during deposition of a turbidity current deposit. Irrespective of their origin, they are still considered by other authors (e.g. Keith and Friedman 1977) to be indicative of 'proximal' environments. The sandstone lithofacies constitute some $72 \%$ of the succession (Hamilton-Smith 1970).

(iii) The remaining $15 \%$ of the succession is composed of thinly bedded laminated and cross-laminated small-scale micaceous and calcareous siltstones and shales with minor carbonates and cherts. These beds probably represent the end products of material reworked by normal bottom currents within the canyon and deposition of pelagic and hemipelagic material carried into deeper water by contour currents, nepheloid layers and, or, dilute turbidity currents. Both processes are active in many modern submarine canyons (see Stanley and Kelling 1978) and produce similar lithofacies. It is within these sediments that, in fact, Hamilton-Smith (1970) made reference to the "obscure trails" described in detail in this paper.

Further evidence that the 'lithic wacke facies' of Hamilton-Smith (1970) represents a submarine canyon-fill is afforded by a more regional and paleocurrent analysis of the Siegas Formation and coeval strata. The Siegas Formation was derived from the north and northwest (Hamilton-Smith 1971a), whereas the coeval Carys Mills Formation, into which the former is erosive, was, in the immediate area, derived from the northeast. The Carys Mills Formation has been recently interpreted by stringer and Pickerill (1980) and Rast and Pickerill (in preparation) as a succession of contourites deposited by deep thermohaline currents on a slope which paralleled the ancient basin margin. The Siegas Formation is therefore a deep channel or submarine canyon which is cut approximately perpendicular into the slope succession of the Carys Milis Formation.

The canyon-fill strata are, unfortunately, generally poorly exposed, though an excellent and almost completely exposed sequence is present in the Siegas Quarry (EMH 558 of Hamilton-Smith 1970). Here approximately $230 \mathrm{~m}$ of strata are continuously exposed and it is from here that the majority of trace fossils described herein were located. Exposures elsewhere are essentially 2-dimensional and somewhat inadequate for the purpose of detailed ichnological analysis.

\section{SYSTEMATIC DESCRIPTIONS}

For ease of reference, trace fossils in the siegas Formation are described alphabetically ( $c f$. Häntzschel 1975) rather than ethologically ( $f f$. Chamberlain 1971). In terms of relative abundance the following format has been adopted: Abundant $=>50$ specimens record́ed, Common $=30-50$ specimens recorded, Frequent $=10-30$ specimens recorded and Rare $=<10$ specimens recorded. Representative examples of specimens described and illustrated in this paper are housed in the Department of Geology, University of New Brunswick. 
Ichnogenus Buthotrephis Hall, 1847

Buthotrephis sp.

$$
\text { (Fig. 2d, 2e) }
$$

Description: Irregularly branched cylindrical or subcylindrical burrows, parallel or slightly oblique to stratification and typically preserved on upper and lower surfaces of shales, calcareous shales and siltstones. Individual burrows may be up to $8 \mathrm{~mm}$ in diameter but are commonly smaller (mean $4 \mathrm{~mm}$ ), posses smooth walls and a burrow fill which is typically of identical grain size to the enclosing sediment. The trace may be distinguished from the morphologically similar ichnogenus Chondrites by its non-systematic branching patterns.

Associated forms: Gordia, Helminthopsis, Neonereites

Relative abundance: Abundant

Discussion: There still exists considerable confusion in the literature regarding the definition and differentiation of the irregularly branched burrows of Buthotrephis and Palaeophycus, and a restudy of both is necessary. Although most of Hall's (1847) original specimens of Buthotrephis are undoubtedly chondritids (Häntzschel 1975, Ksiaźkiewicz 1977) some of them (e.g. B. palmata and $B$. succulens) cannot be justifiably assigned to chondrites. $B$. palmata may in fact belong to the ichnogenus Phycodes Richter, 1850 but a restudy of Hall's material is necessary to resolve this. Similarly, Palaeophycus is also a poorly defined ichnogenus, with some authors (e.g. Osgood 1970, Chamberlain 1977) assigning only unbranched or sparsely branched forms, and others (e.g. Alpert 1975, Pickerill and Forbes 1979) assigning irregularly branched forms to this ichnogenus. The majority of Hall's
(1847, 1952) specimens of Palaeophycus exhibit longitudinal striations, whereas Buthotrephis is more typically smooth. As the Siegas material is irregularly branched and has smooth walls, it is therefore diagnosed as Buthotrephis, but in view of the confusion, only at ichnogeneric level.

Buthotrephis is a facies crossing ichnogenus, Cambrian-Recent in age, and probably represents the feeding burrow of an infaunal polychaete annelid (Ksiaźkiewicz 1977).

Ichnogenus Chondrites

von Sternberg, 1833

Chondrites sp.

(Fig. 2g)

Description: Plantlike dendritic patterns of small burrows, individual tunnels neither crossing nor intersecting. Burrow diameter ranges from 4-8 $\mathrm{mm}$ but is consistent within individual specimens. The burrows are generally observed parallel to stratification on both upper and lower surfaces of shales, calcareous shales and siltstones. Two and three orders of branching, generally in regular pinnate or variable patterns, may be observed. Branching angles vary, even within individual specimens, from between $20-50^{\circ}$.

Associated forms: Gordia, Helminthopsis, Planolites, Neonereites

Relative abundance: Abundant

Discussion: The facies crossing ichnogenus Chondrites, which ranges in age from Cambrian-Recent, is an extremely variable form. Many ichnospecies of the trace purportedly exist (e.g. Chamberlain 1977), the majority subjectively based on variations in size, preservation and angle of branching. In view of the generally poor preservation of the 
Siegas material and the unsatisfactory taxonomic status of the ichnogenus, it is here only identified at ichnogeneric level.

Chondrites is normally regarded as a feeding burrow of sipunculid annelids (Simpson 1947); tiny arthropods (Ekdale 1977) or unknown tentacle-bearing organisms (Taylor 1967).

\section{Ichnogenus Cochlichnus \\ Hitchcock, 1858}

Cochlichnus anguineus Hitchcock, 1858 (Fig. 2c)

Description: Smal1, regularly sinusoidal traces, parallel to stratification and commonly preserved in convex hyporelief and more rarely in concave epirelief. specimens are generally $1 \mathrm{~mm}$ in diameter, up to $70 \mathrm{~mm}$ in length and smooth throughout their extent. occasionally a slight thickening may be observed at the apices of the meanders.

Associated forms: Diplichnites, Gordia, Neonereites

Relative abundance: Frequent

Discussion: The ichnogenus CochTichnus is a facies crossing form, having previously been described from a wide range of palaeoenvironments of late Precambrian-Tertiary age. It is generally regarded to have been produced by nematodes or annelids lacking well-developed parapodia (Michelau 1956, Hakes 1976). The trace may represent a true burrow, as in the case of Cochlichnus serpens (see Webby 1970), but this is impos- sible to ascertain with the Siegas material, as diagenesis has masked its former nature. For this reason, the material is included within the ichnospecies $C$. anguineus, as Hitchcock (1958) described the trace as a 'trackway' and not a burrow.

Ichnogenus Diplichnites Dawson, 1873 Diplichnites sp.

$$
\text { (Fig. 2h, 5f) }
$$

Description: Paired rows of small dot-like or slightly elongate (normal to the trace axis) imprints, approximately $1 \mathrm{~mm}$ in diameter. In rare examples the imprints assume an obtuse V-shape rather than simply being elongate. The pairs of imprints remain separated and evenly spaced throughout the length of the trace. The width of an individual set is $4-6$ mm. Dactyl impressions are absent.

Associated forms: Cochlichnus, Gordia

Relative abundance: Frequent

Discussion: Diplichnites is a morphologically simple trace and is usually interpreted as the walking track of a trilobite (Crimes et a 2., 1977). It has been reported in rocks of Cambrian-Permian age (Häntzschel 1975) and is regarded as a typical shallow water (neritic) form (e.g. Crimes, 1975). The recording by Pickerill (1980) and this example here now extend its environmental distribution to deeper water strata. Although the preservation of the Siegas material is not sufficiently good for ichnospecific iden-

Fig. 2 a. Skolithos sp. in thinly bedded, parallel laminated calcareous silts and shales. b. Helminthopsis $c f$. abeli on sole of turbiditic sandstone. c. Cochlichnus aniguineus on sole of laminated siltstone. d. Goraia sp. in association with small Buthotrephis sp. on sole of calcareous shale. e. Buthotrephis $\mathrm{sp}$. on upper surface of parallel laminated calcareous siltstone. f. Scalarituba missouriensis on upper surface of calcareous shale. g. Chondrites sp. on sole of parallel laminated calcareous shale. h. Diplichnites sp. on side of parallel laminated siltstone. Bar scale $=1 \mathrm{~cm}$. 


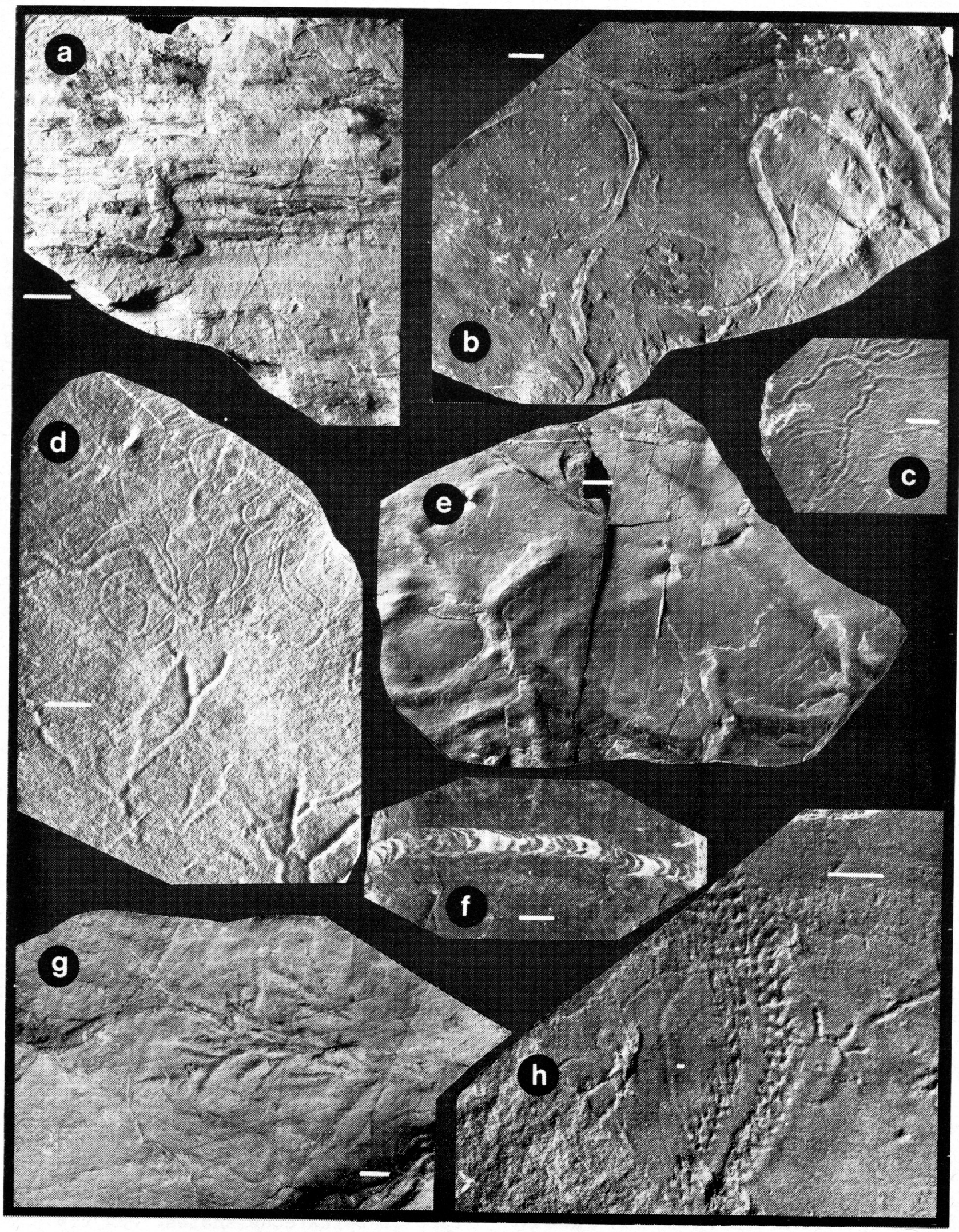


tification, the specimens closely resemble osgood and Drennen's (1975) Type A Diplichnites from the Silurian Clinton Group of New York State.

\section{Ichnogenus Fucusopsis}

Palibin in Vassoevich, 1932 Fucusopsis sp.

(Fig. 5b)

Description: Straight to slightly curved, longitudinally striated cylindrical burrows up to $12 \mathrm{~mm}$ in length that are unbranched and parallel to stratification. The burrows are clearly post-depositional in origin, up to $10 \mathrm{~mm}$ in diameter and may occur as solitary specimens or in groups on the same bedding plane. The most common mode of preservation is in convex hyporelief and the burrow fill is typically of the same grain size and, or, slightly coarser than the enclosing sediment.

Associated forms: Chondrites, Gordia, Helminthopsis, Planolites Relative abundance: Frequent

Discussion: Though a number of ichnospecies of Fucusopsis have been described (see Ksiażkiewicz 1977), the Siegas material is not well enough preserved for ichnospecific assignment. Furthermore, some specimens are apparently intermediate between $F$. angulata Palibin, 1932, where the longitudinal striations are discontinuous, and F. striata Hall, 1852, where the striations are continuous and more closely spaced. In view of this, the material is only identified at ichnogeneric level.

Fucusopsis is a well documented facies crossing form ranging in age from Ordovician-oligocene, and represents the feeding burrow of an infaunal organism (? annelid), the ridge-like sculptures, according to Seilacher (1959), appar- ently reflecting the burrowing activity of its producer.

Ichnogenus Gordia Emmons, 1844 Gordia arcuata Ksiażkiewicz, 1977

(Fig. 3b)

Description: Thin, thread-sized burrows preserved in convex hyporelief and all assuming an incomplete loop-like (arcuate) form. The burrow diameter is $1 \mathrm{~mm}$ and the surface is always smooth. The burrow fill is typically of identical grain size as the enclosing sediment. Specimens may be differentiated from the morphologically similar trace Furculosus

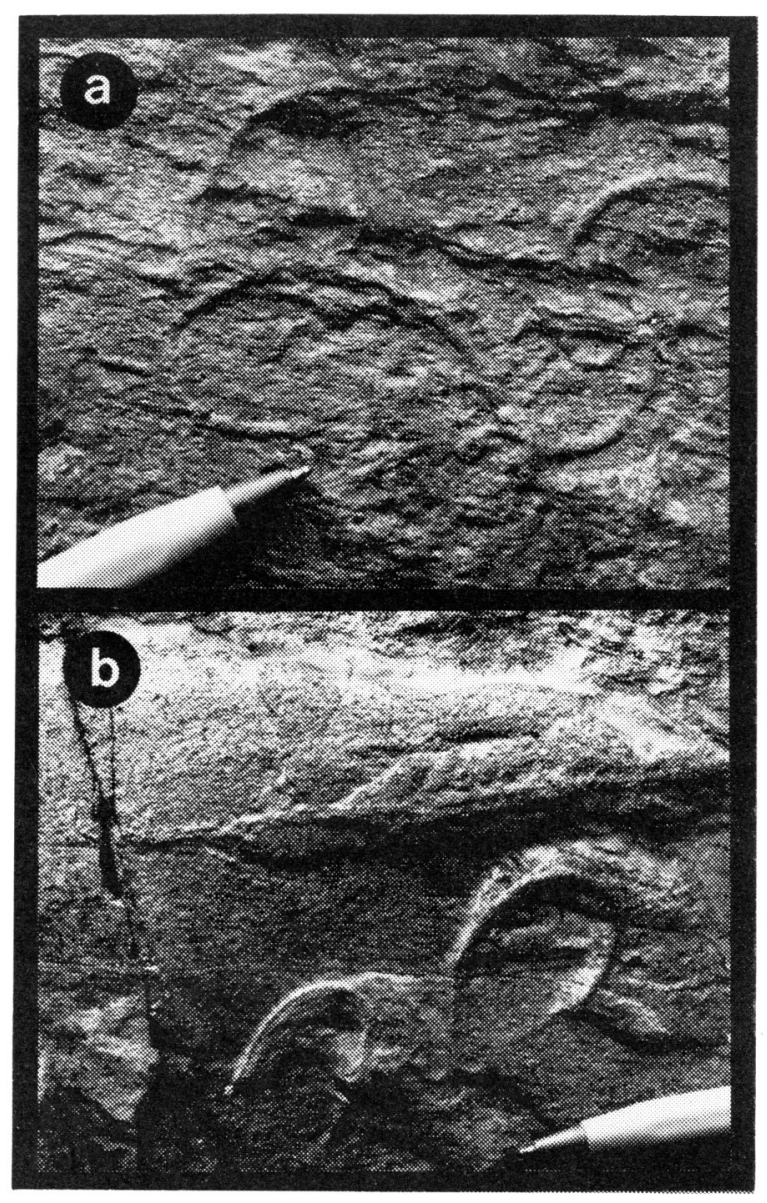

Fig. 3-Field photographs of Gordia sp. (a) and Gordia arcuata (b) on upper surface of calcareous shales. Pen tip $=9$ $\mathrm{mm}$. 
carpathicus Roniewicz and Pienkowski, 1977 by their more arcuate shape and smaller burrow diameter.

$$
\begin{gathered}
\text { Gordia sp. } \\
\text { (Fig. 2d, 3a) }
\end{gathered}
$$

Description: Slender thin burrows preserved in convex hyporelief and convex/concave epirelief which wind and curve non-systematically and cross-cut in an irregular manner. The burrows are smooth and up to $2 \mathrm{~mm}$ in diameter. The burrow fill is typically of identical grain size as the enclosing sediment. The traces can be differentiated from the morphologically similar trace Helminthopsis in that they commonly cross-cut one another.

Associated forms: Buthotrephis, Chondrites, Cochlichnus, Diplichnites, Fucusopsis, Helminthopsis, Neonereites

Relative abundance: Gordia arcuata - Rare, Gordia - Abundant

Discussion: Gordia arcuata, recently described from flysch of the Polish Carpathians by Ksiażkiewicz (1977), is a rare form in the Siegas Formation but can be clearly distinguished by its distinctive morphology. The second form, however, resembles both the type specimen $G$. marina, as for example recently figured by Chamberlain (1977), and G. molassica as described by Heer (1865). The latter may, in fact, prove to be a junior synonym of $G$. marina, as the two ichnospecies appear to be identical. Until the detailed synonymy is resolved, the Siegas material is only identified at ichnogeneric level.

Gordia is a facies crossing ichnogenus of late Precambrian-oligocene age and, according to Ksiazkiewicz (1977) and Chamberlain
(1977), probably represents the post-depositional feeding burrow of a polychaete annelid.

Ichnogenus Gyrochorte Heer, 1865 Gyrochorte sp.

$$
\text { (Fig. 5e) }
$$

Description: Cylindrical or subcylindrical bilobate burrows of post-depositional origin and up to $15 \mathrm{~mm}$ in diameter and a maximum observed length of $123 \mathrm{~mm}$. The burrows are straight to slightly curved and are characterized by the development of a distinctive obliquely transverse, densely spaced but irregular, biserial surface ornament, consisting of incisions which join in' a medium and generally shallow apical groove The burrow fill is typically of silt grade whereas the burrows cut thinly laminated silts and shales. They are commonly preserved in convex epirelief, though hyporelief preservation has been rarely observed.

Associated forms: Unknown

Relative abundance: Frequent

Discussion: A number of ichnospecies of Gyrochorte have been described in the literature (see Hallam 1970, Häntzschel 1975, Ksiazkiewicz 1977) but the Siegas material is not well enough preserved and, or sufficiently abundant to warrant formal ichnospecific identification. It is also apparent that the criteria presently adopted for ichnospecific separation of Gyrochorte are somewhat subjective and therefore at this time the present author prefers an ichnogeneric assignment. Nevertheless, the traces do resemble $G$. obiterata Ksiazkiewicz, 1977 in that the median groove is shallow and the oblique incisions are irregular and dense- 
Iy spaced, but differs from this ichnospecies in that the ribbing is usually well-developed. The Siegas material is wider than $G$. cosmosa Heer, 1865 and $G$. imbricata Ksiazkiewicz 1977, but narrower than $G$. burtani Ksiazkiewicz, 1977.

Gyrochorte is 'normally' regarded as a shallow water neritic form (e.g. Seilacher 1978) though deep water recordings have also been made (e.g. Ksiażkiewicz 1977, Pickerill 1980). It ranges in age from Ordovician-oligocene and was most probably produced by the burrowing activity of small amphipods (Abel 1935) or annelids (Heinberg 1973).

Ichnogenus HeIminthoida Schafhaut1, 1851

Helminthoida labyrinthica Heer, 1865

$$
\text { (Fig. 5c, 5d) }
$$

Description: Tightly spaced, regularly and parallel meandering burrow system, the burrow width being 5-6 mm, separated from adjacent meanders by $1-2 \mathrm{~mm}$ of sediment. Individual meanders are curved and occasionally even coiled. Typically, an individual meander is 4-5 cm high. The trace is generally poorly preserved and has only been observed in float material in calcareous siltstones.

\section{Associated forms: Neonereites}

Relative abundance: Rare

Discussion: Helminthoida is a characteristic deep water trace fossil, usually associated with the Nereites ichnofacies of Seilacher (1967). Although $H$. labyrinthica is commonly regarded as a Mesozoic form (Häntzschel 1975), it has recently been recorded (Pickerill 1980, Fig. 3c) from ordovician strata. Crimes (1977) noted that its most common occurrence was in association with outer fan and basin plain environments. The recording here thus extends its environmental range to submarine canyons.

Helminthoida has been recorded from ordovician-oligocene strata and is normally regarded as the grazing product of worm-like organisms, presumeably polychetes (Ksiażkiewicz 1977).

Ichnogenus Helminthopsis Heer, 1877 Helminthopsis of. albeli

Ksiazkiewicz, 1977

$$
\text { (Fig. 2b). }
$$

Description: Irregularly and loosely winding or meandering unbranched burrows, parallel and, or, sub-parallel to stratification, and usually preserved in convex hyporelief, rarely in concave epirelief. Burrow diameter ranges between $3-7 \mathrm{~mm}$ but is consistent for a single specimen. The burrows are cylindrical and, or subcylindrical, smooth throughout their extent and in contrast to the related ichnogenus Gordia, never intersect. The winding or meandering path is extremely variable and non-systematic. Specimens are preserved in shales, calcareous shales and, or, siltstones.

Associated forms: Buthotrephis, Chondrites, Fucusopsis, Gordia, Neonereites, Planolites

\section{Relative abundance: Abundant}

Discussion: Based on the parameters presently adopted for ichnospecific assignment of Helminthopsis, viz:- the nature and type of winding, the burrow diameter and the presence or absence of surface ornamentation (Ksiàkiewicz 1977), a number of ichnospecies have been proposed. However, the Siegas material exhibits 


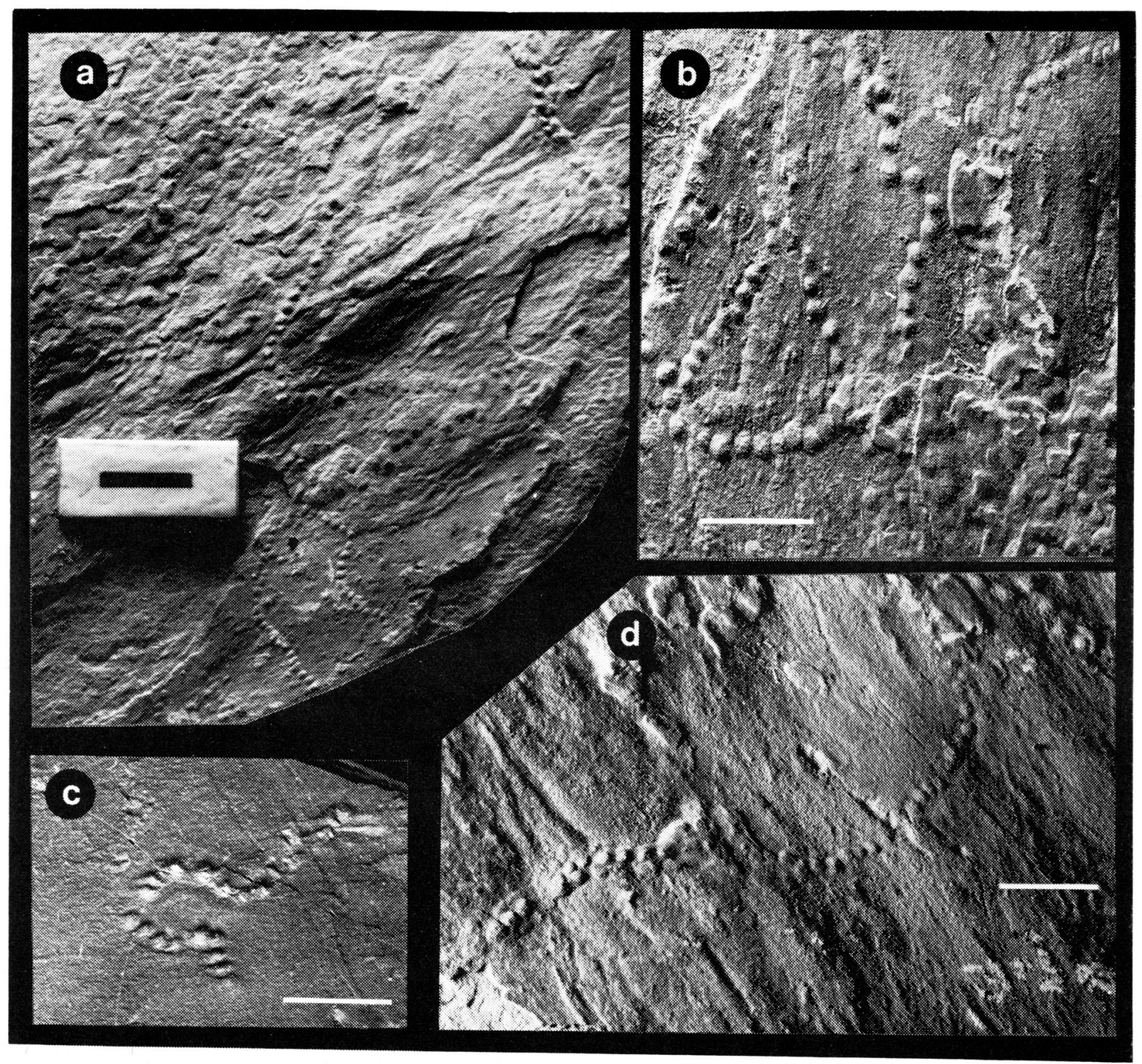

Fig. 4 Variation in Neonereites spp. from the Siegas Formation; a illustraces both $N$. uniserialis and $N$. biserialis (upper right), b and $c$ show $N$. uniserialis and $\mathrm{d}$ shows $N$. uniserialis progressing in to $N$. biserialis. All specimens are sole structures preserved in calcareous shales. Bar scale $=1 \mathrm{~cm}$.

variable winding and meandering patterns within a single specimen and different burrow diameters may exhibit the same or different behavioural patterns. Nevertheless, the material is closely comparable, both in terms of burrow diameter and the variable and loosely winding and meandering patterns, to Helminthopsis abei $i$ and is tentatively diagnosed-as such. In view of the considerable variation, however, it is deemed that previously adopted ichnospecific criteria are perhaps unsatisfactory and are in need of careful reassessment.

Helminthopsis is a facies crossing form, though more commonly rel ported from deep water successions. It ranges in age from Cambrian-oligocene and is regard- 


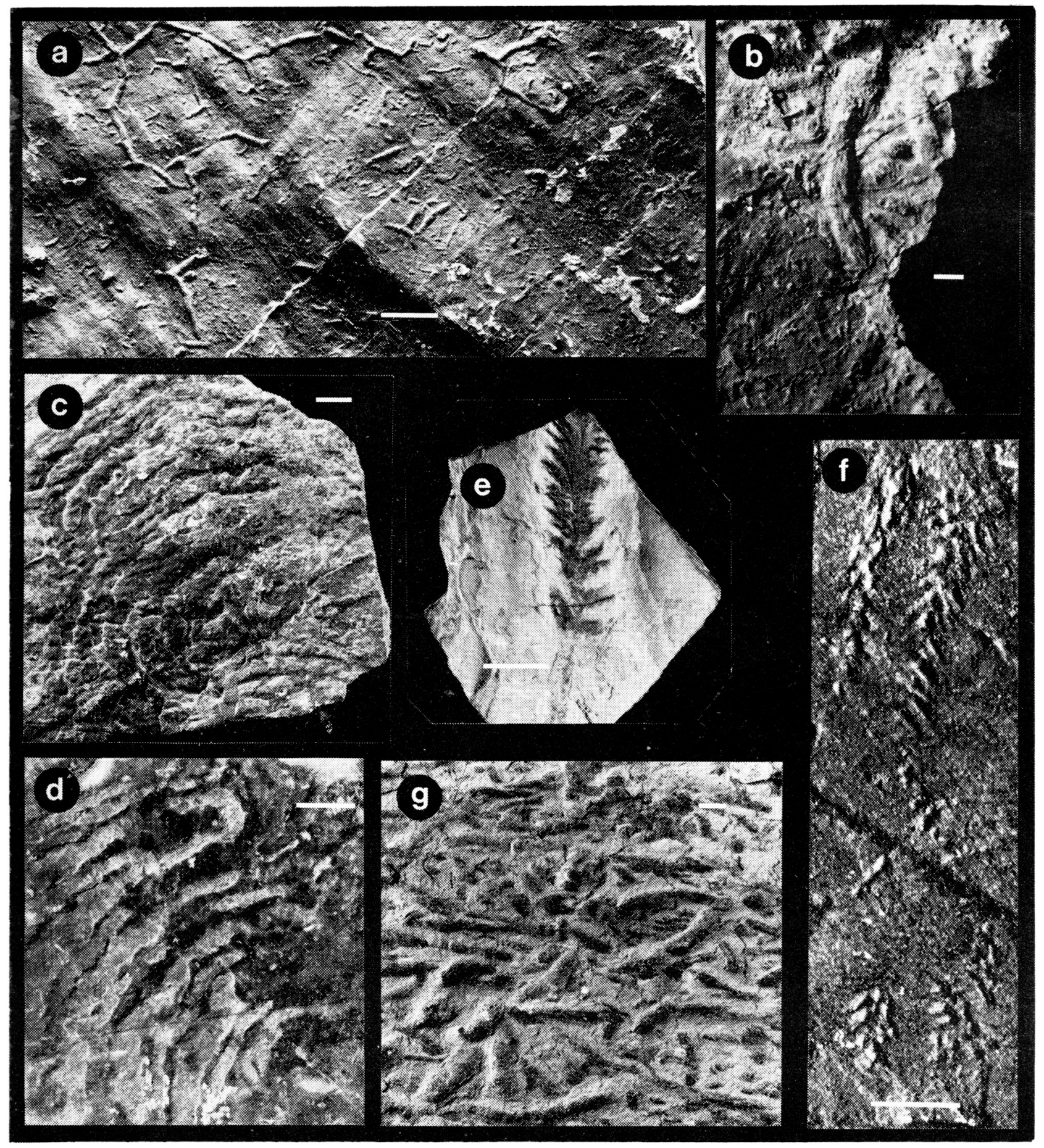

Fig. 5 - a Protopaleodictyon sp. on sole of current fluted (top left to bottom right) turbidite sandstone. b. Fucusopsis sp. on sole of turbiditic sandstone. c-d. Helminthoida labyminthica on upper surface of parallel laminated calcareous shale. Note the poor preservation. e. Gyrochorte sp. on sole of calcareous siltstone. f. Diplichnites sp. on sole of parallel laminated siltstone. g. Planolites beverleyensis on sole of parallel and cross laminated calcareous siltstone. Bar scale $=1 \mathrm{~cm}$. 
ed as having been produced by polychete annelids (Ksiażkiewicz 1977).

\author{
Ichnogenus Neonereites \\ Seilacher, 1960 \\ Neonereites uniserialis \\ Seilacher, 1960
}

$$
\text { (Fig. 4) }
$$

Description: Sinuous or curved chains of closely spaced rows of uniserially arranged subcircular to oblong knobs preserved in convex hyporelief. The long axis of individual knobs is normal to the chain length and varies in size from 1-4 mm. Individual chains, however, are composed of knobs of the same size. In general, adjacent knobs do not come into contact, though the gap is extremely small, commonly $<1 \mathrm{~mm}$. The chain shape and length exhibit considerable variation - some are sinelike and up to a length of $300 \mathrm{~mm}$, some are horseshoe-shaped but the majority are irregular. Occasionally the trace is preserved in concave epirelief as a series of closely spaced depressions.

Neonereites biserialis Seilacher, 1960

$$
\text { (Fig. 4) }
$$

Description: In contrast to $N$. uniserialis, Neonereites biserial$i s$, the type species of the ichnogenus, consists of chains of two closely spaced rows of subcircular knobs preserved in convex hyporelief. Knobs of adjacent rows are not opposite but alternate in position. As with $N$. uniserialis, the chain shape, length and width vary considerably, though the latter is again consistent within an individual specimen. The trace is only rarely preserved in concave epirelief.

Associated forms: Buthotrephis,
Chondrites, Gordia, HeIminthoida, Helminthopsis, Planolites

Relative abundance: $N$. uniserialis - abundant, $N$. biserialis common.

Discussion: Neonereites is a Iacies crossing ichnogenus, probably representing the fodinichnia of infaunal annelids (Hakes 1976) and has been recorded from strata of late Precambrian-Tertiary age (Häntzschel 1975, Fedonkin 1977). Seilacher and Meischner (1964) grouped Neonereites with the ichnogenera Nereites and Scalarituba but not as strict synonyms, but later Chamberlain (1971) regarded Nereites and Neonereites as preservational variants of scalarituba. Subsequent authors, however, aga in separated these three related ichnogenera (e.g. Häntzschel 1975 , Hakes 1976, Brasier and Hewitt 1979). In view of their distinctive morphology and the absence of Scalarituba-like and, or, Nereites - like preservation (as recorded by careful sectioning of the traces), Neonereites is also regarded here as a separate and distinctive ichnogenus.

Although the two distinctive ichnospecies $N$. uniserialis and N. biserialis are generally easily separated, occasional specimens from the Siegas Formation exhibit transitional forms with one passing directly into the other (Fig. 4d), thus providing yet a further example of the persistent nomenclatural difficulties faced by ichnologists $(c f$. Bromley and Frey 1974, Frey and Seilacher 1980).

Ichnogenus Planolites Nicholson, 1873 Planolites beverleyensis Billings, 1862

(Fig. 5g)

Description: Unbranched, smooth- 
walled cylindrical, subcylindrical and flattened sediment filled burrows, generally parallel and rarely sub-parallel to stratification. The burrows are straight or only slightly curved, thus distinguishing them from the morphologically similar trace Helminthopsis, which is characterized by loose winding and, or, meandering patterns. The sediment fill may be coarser, finer or of identical grain size to the enclosing sediment, which is commonly calcareous siltstone. The burrow diameter varies from 3-12 $\mathrm{mm}$ and is typically consistent within an individual trace.

Associated forms: Chondrites, Fucosopsis, Helminthopsis, Neonereites, Protopaleodictyon.

Relative abundance: Abundant

Discussion: Planolites is a facies crossing ichnogenus ranging in age from late Precambrian-Recent (Häntzschel 1975) and commonly. attributed to the burrowing activity of annelids (Hallam 1970). It is similar to Palaeophycus Hall, 1847 and the distinction between these two ichnogenera still remains controversial. Following Häntzschel (1975), Alpert (1975) and McCarthy (1979), however, Palaeophycus is only available for irregularly branched burrows. Furthermore, Palaeophycus buriows also commonly possess irregular walls which often display collapse structures (Frey and Chowns 1972). The Siegas material is therefore diagnosed as Planolites. The taxonomy of Planolites has been recently reviewed by Alpert (1975) and the Siegas material is identical to $P$. beverleyensis.

Ichnogenus Protopaleodictyon Ksiazkiewicz, 1970
Protopaleodictyon sp.

(Fig. 5a)

Description: Thread-like, incomplete network burrow system, $2 \mathrm{~mm}$ in width and smooth throughout their length. Each system consists of wide first order meanders upon which are superimposed smaller second order sine-shaped undulations with distinct appendages. The trace is horizontal and preserved on the sole of current fluted turbidite sandstones.

Associated forms: Planolites

Relative abundance: Rare

Discussion: There is still no general agreement on what constitutes a distinctive ichnospecies of the graphoglyptid trace Protopaleodictyon, with seilacher (1977) utilizing the number of branches/undulation and Ksiazkiewicz (1977) the regularity and spacing of the first order meanders and the size and thickness of the strings. In view of this inconsistency, the Siegas material is only identified at ichnogeneric level. Protopaleodictyon is a deep water trace fossil characteristic of the Nereites ichnofacies of Seilacher (1967). It ranges in age from ordovician-Tertiary and was presumeably constructed by some unknown infaunal annelid.

Ichnogenus Scalarituba Weller, 1899 Scalarituba missouriensis Weller, 1899

(Fig. 2f)

Description: Straight, curved or winding traces preserved in concave epirelief and up to $6 \mathrm{~mm}$ in width and variable length. Each trace is characterized by closely spaced crescentric partitions which are transversely oriented and distinguishable by slight colour 
variation from one to the next. The traces are preserved in dark shales and have only been observed in float material.

\section{Associated forms: Unknown}

Relative abundance: Frequent

Discussion: Scalarituba is a monotypic ichnogenus and has been previously reported from environments ranging from tidal flat (Conkin and Conkin 1968) to deep water flysch (Seilacher and Meischner 1965, Chamberlain 1971, Pickerill 1980). It ranges in age from ordovician-Permian and represents the activity of worms burrowing within the sediment and episodically back-filling the burrows, thereby creating the transverse partitions (Hakes 1976).

Ichnogenus Skolithos Haldeman, 1840
Skolithos sp. (Fig. 2a)

Description: Smooth and unlined, vertical or slightly oblique, cylindrical or subcylindrical, unbranched burrows which frequently possess irregular walls. The burrows may be isolated or clustered but never densely crowded. Burrow diameter ranges up to an observed maximum of $8 \mathrm{~mm}$. Burrow fill is generally coarser than the enclosing sediment, which is typically laminated calcareous shale.

Associated forms: Unknown, as the trace is only observed in vertical section.

Relative abundance: Abundant

Discussion: Skolithos is an ichnogenus of late Precambrian-Recent age and represents the dwelling burrow of annelids or phoronids (Alpert 1974). The presence of abundant specimens is usually indicative of a shallow marine environment (Seilacher 1967) though deep water recordings have also been made (e.g. Hayward 1976 , Crimes 1977). The Siegas material also resembles Tigillites Rouault, 1950, which is usually reserved for noncrowded vertical burrows. However, burrow density is regarded as a palaeoecological variable and should not be utilized in taxonomic decisions. Tigillites is therefore regarded as a junior synonym of skolithos. Because of the unsatisfactory taxonomic status of the trace at the present time, the specimens are only identified at ichnogeneric level.

\section{DISCUSSION}

It must be emphasized that the trace fossils described in this paper are from strata deposited within the canyon and not the canyon walls. The latter are generally poorly exposed in the Siegas area, and where present (see Hamilton-Smith 1970), no trace fossils have been observed in association with them. It must also be noted that the traces generally occur in seaiments of category (iii) as outlined previously, or, alternatively, as sole structures on the base of turbidites described under category (ii). No trace fossils were observed in association with the organized and disorganized resedimented conglomerates of category (i).

The majority of the variety of trace fossils described from the Siegas Formation, which are shown schematically in Figure 6 , are well-known facies crossing forms, having been previously reported from a variety of shallow and deep water environments. These include Buthotrephis, Chondrites, Cochlichnus, Fucusopsis, Gordia, Gyro- 


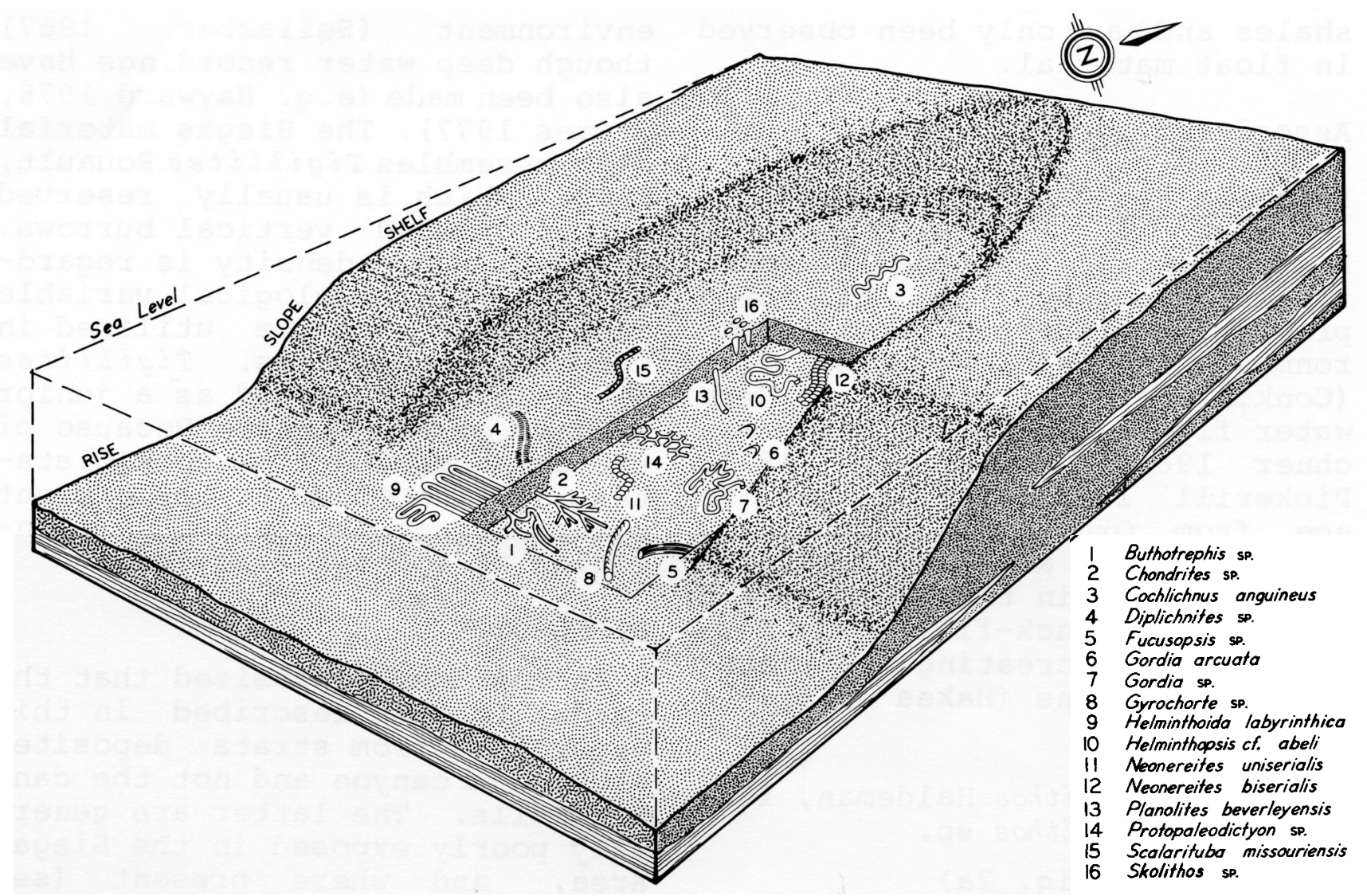

Fig. 6 - Schematic representation of the Siegas Formation submarine canyon ichno-assemblage. No scale is implied.

chorte, Neonereites, Planolites and scalarituba. The assemblage does, however, contain the typical or more typical "shallow water" traces Skolithos and Diplichnites and those commonly recorded in the Nereites ichnofacies of Seilacher (1967) in middle fan, outer fan and trough sediments, Helminthoida, Helminthopsis and Protopaleodictyon. Diplichnites, Helminthoida, Helminthopsis and Protopaleodictyon represent new trace fossil recordings in submarine canyon sequences (see Crimes 1977, Table 4, p. 80), whereas, as mentioned previously, Skolithos has already been recorded. To this list of new recordings must be added Zoophycos $(=$ Zoophycus $)$ and Nereites, recently noted by Stanley et al. (1978) from Eocene canyon-fill strata of the French Maritime Alps. Unfortunately Crimes (ibia.) does not mention which facies crossing ichnogenera are likely to be present in submarine canyon sequences (with the exception of Chondrites, Neonereites and scolicia), but if the Siegas material is representative, the list is likely to be a reasonably extensive one providing that the trace fossils are preserved and not eroded by periodically powerful currents.

The mutual occurrence of "shallow" and "deep" traces in association with the facies crossing variety suggests that substrate, 
food availability, temperature and/or ecological interactions rather than bathymetry per se were important parameters regarding their presence ( $f$. Crimes 1970, Frey and Howard 1970). Contrary to the proposal by Crimes $(1977$, p. 79$)$ regarding ancient submarine canyon ichnofaunas, the assemblage is composed essentially of traces produced by vagile infaunal sediment eaters and grazers and does not include dwelling burrows. In fact, the 'anticipated' submarine canyon traces of Crimes (ibid.) viz:- the dwelling burrows Arenicolites, Corophioides, Diplocraterion, Monocraterion and ophiomorpha and Thalassinoides, are all absent. The absence of ophiomorpha and Thalassinoides is hardly surprising, as these trace fossils have yet to be recorded in Lower Palaeozoic sediments (Häntzschel 1975). The absence of the additionally listed dwelling burrows, however, cannot be reconciled stratigraphically, as all these traces have been commonly observed and recorded in many sequences of Lower Palaeozoic age. However, these ichnogenera are most commonly recorded in shallow water environments, themselves characterized by active and medium-high velocity currents. Indeed, the presence of active bottom currents to provide sufficient organic material and water turbulence appears to have been particularly important regarding the occurrence of these latter traces, which are all produced by filter feeding (? annelid) organisms. Crimes (op. cit.), in fact, predicted their presence in submarine canyon sequences for this very reason.

Nevertheless, recent observations by shepard et al. (1979), have demonstrated that relatively slow velocity currents can be commonplace in modern submarine can- yons. Sedimentological considertions would tend to confirm that this situation probably existed for the majority of time in the Siegas Formation, and currents only became periodically strong with the introduction of mass-flow deposits. This is also suggested by the good preservation of the delicate traces produced at the sediment-water interface, such as Diplichnites and Neonereites, which show no evidence of fluting by currents ( $f f$. Crimes 1973) or rheotactic orientation. The absence of traces produced by filter feeding organisms in the siegas Formation may therefore well be related (in addition to the potential preservational difficulties) to the absence of sufficiently strong bottom currents, which, in turn, precluded the presence of an active and abundant suspension feeding population of organisms. Instead, the Siegas Formation is characterized by traces produced by deposit feeders, particularly infaunal deposit feeders, thus suggesting that the sediments contained sufficiently abundant organic detritus to support such a population of organisms.

Crimes (1977) also noted that submarine canyon environments could probably only support an ichnofauna of low abundance and diversity. Nevertheless, and indeed as noted by Crimes himself, data on submarine canyon environments is sparse. This particular conclusion was based on the assumption that medium-coarse grained sandy substrates swept by fastflowing currents could not support a diverse population of organisms. As outlined above, however, current conditions are extremely variable and, in addition, modern canyons are characterized by a variety of substrate types (Shepard et al. 1979). This study has, in 
fact, recorded a minimum of 14 ichnogenera (16 ichnospecies), which according to the latest proposed Phanerozoic trace fossil diversity models (Frey and Seilacher 1980), is diverse for deep water strata of Silurian age. In addition, many of the traces can also be termed abundant in the sense that over 50 specimens of each were recorded over a large stratigraphic interval.

In conclusion, therefore, this example of an ancient submarine canyon sequence has demonstrated that such strata may, in fact, possess a wide variety of trace fossils, comparable in many respects to other ancient deep sea environments. Although data on ancient submarine canyon sequences is still sparse, it is anticipated that as research is undertaken in comparable sequences, similarly diverse trace fossil assemblages will be revealed. Only with the careful collection and description of trace fossil material will meaningful and realistic models of submarine canyon ichnocoenoses through time be realized.

\section{ACKNOWLEDGEMENTS}

I wish to thank Drs. T. Harland and $W$. Forbes for their critical reviews of the original manuscript and S. Townsend, G. Landry and R. McCulloch for their technical assistance during its preparation. D. Fillion provided the French translation of the abstract. This work was undertaken during the tenure of N.S.E.R.C. Grant A3857 which is gratefully acknowledged.

ABEL, 0. 1935. Vortzeitliche Lebensm spuren. Gustav Fischer (Jena), 644p.

ALPERT, S. 1974. Systematic review of the genus Skolithos. Journal of Paleontology, 48, pp. 661-669.

1975. Planolites and Skolithos

from the Upper Precambrian-Lower Cam- brian, White-Inyo Mountains, California. Journal of Paleontology, 49, pp. 508-521.

AYRTON, W.G., BERRY, W.B.N., BOUCOT, A. J., LAJOIE, J., LESPËRANCE, P.I., PAVLIDES, L. and SKIDMORE, W.B. 1969. Lower Llandovery of the Northern Applachians and Adjacent Regions. Bulletin of the Geological Society of America, 80, pp. 459-484.

BATES, R.L. and JACKSON, J.A., Editors 1980. Glossary of Geology American Geological Institute, Falls Church, Virginia, 2nd edition, 749p.

BRASIER, M.D. and HEWITT, R.A. 1979. Environmental setting of fossiliferous rocks from the uppermost Proterozoiclower Cambrian of central England. Palaeogeography, Palaeoclimatology, Palaeoecology, 27, pp. 35-57.

BROMLEY, R.G. and FREY, R.W. 1974. Redescription of the trace fossil Gyrolithes and taxonomic evaluation of Thalassinoides, Ophiomorpha and Spongeliomorpha. Bulletin of the Geological Society of Denmark, 23, pp. 311335.

CHAMBERLAIN, C.K. 1971. Morphology and ethology of trace fossils from the Ouachita Mountains, southeast Oklahoma. Journal of Paleontology, 45, pp. 212-246.

1977. Ordovician and Devonian trace fossils from Nevada. Nevada Bureau of Mines and Geology, Bulletin 90, 24p.

CONKIN, J.E. and CONKIN, B.M. 1969. Scalarituba missouriensis and its st ratigraphic distribution. University of Kansas Paleontological Contributions, Paper 31, 7p.

CRIMES, T.P. 1970. The significance of trace fossils in sedimentology, stratigraphy and palaeoecology with examples from Lower Palaeozoic strata. In Trace fossils. Edited by T.P. Crimes and J. C. Harper. Geological Journal Special Issue Number 3, Seel House Press, Liverpool, pp. 101-126. 
1973. From 1imestones to distal turbidites: a facies and trace fossil analysis in the Zumaya flysch (Paleocene-Eocene), North Spain. Sedimentology, 20, pp. 105-131.

1975. The stratigraphical significance of trace fossils. In The Study of Trace Fossils. Edited by R.W. Frey. Springer-Verlag, Berlin, Heide1berg, New York, pp. 109-130.

1977. Trace fossils of an Eocene deep-sea sand fan, northern Spain. In Trace fossils 2. Edited by T.P. Crimes and J.C. Harper. Geological Journal Special Issue Number 9, Seel House Press, Liverpool, pp. 7190.

CRIMES, T.P., LEGG, I., MARCOS, A. and ARBOLEYA, M. 1977. ? Late Precambrianlow Lower Cambrian trace fossils from Spain. In Trace Fossils 2. Edited by T.P. Crimes and J.C. Harper. Geological Journal Special Issue Number 9, Seel House Press, Liverpool, pp. 91138 .

DILLON, W.P. and ZIMMERMAN, H.B. 1970. Erosion by biological activity in two New England submarine canyons. Journal of Sedimentary Petrology, 40, pp. 542547.

DOYLE, L.J. and PILKEY, O.H., Editors. 1979. Geology of Continental Slopes. Society of Economic Paleontologists and Mineralogists Special Publication Number 27, 374p.

EKDALE, A.A. 1979. Abyssal trace fossils in worldwide Deep Sea Drilling Project cores. In Trace fossils 2. Edited by T.P. Crimes and J.C. Harper. Geological Journal Special Issue Number 9, Seel House Press, Liverpool, pp. 163-182.

FEDONKIN, M.A. 1977. Precambrian-Cambrian ichnocoenoses of the east European platform. In Trace fossils 2 . Edited by T.P. Crimes and J.C. Harper. Geological Journal Special Issue Number 9, Seel House Press, Liverpool, pp. 183-194.

FREY, R.W. and HOWARD, J.D. 1970. Com- parison of Upper Cretaceous ichnofaunas from siliceous sandstones and chalk, Western Interior Region,U.S.A. In Trace fossils. Edited by T.P. Crimes and J.C. Harper. Geological Journal Special Issue Number 3, Seel House Press, Liverpool, pp. 141-166.

FREY, R.W. and CHOWNS, T.M. 1972. Trace fossils from the Ringgold road cut (Ordovician and Silurian). Georgia. In Sedimentary environments in the Paleozoic rocks of northwest Georgia. Compized by T. M. Chowns. Geological Survey of Georgia Guidebook 11, pp. 25-55.

FREY, R.W. and SEILACHER, A. 1980. Uniformity in marine invertebrate ichnology. Lethaia, 13, pp. 183-207.

HAKES, W.G. 1976. Trace fossils and depositional environment of four clastic units, Upper Pennsylvanian megaclothems, northeastern Kansas. University of Kansas Paleontological Contributions, Article 63, 46p.

HALL, J. 1847. Paleontology of New York. State of New York (Albany, N.Y.), volume $1,338 \mathrm{p}$.

1852. Paleontology of New York. State of New York (Albany, N.Y.), volume $2,362 \mathrm{p}$.

HALLAM, A. 1970. Gyrochorte and other trace fossils in the Forest Marble (Bathonian) of Dorset, England. In Trace fossils. Edited by T.P. Crimes and J.C. Harper. Geological Journal Special Issue Number 3, Seel House Press, Liverpool, pp. 189-200.

HAMILTON-SMITH, T. 1970. Stratigraphy and structure of Ordovician and Silurian rocks of the Siegas area, New Brunswick. Mineral Resources Branch, Department of Natural Resources, New Brunswick, Report of Investigation No. 12, 55p.

1971a Paleogeography. of northwestern New Brunswick during the Llandovery, a study of the provenance of the Siegas Formation. Canadian Journal of Earth Sciences, 8, pp. 196-203. 
1971b. A proximal-distal turbidite sequence and a probable submarine canyon in the Siegas Formation (Early Llandovery) of northwestern New Brunswick. Journal of Sedimentary Petrology, 41, pp. 752-762.

1980. Stratigraphy and sedimentology of the Siegas Formation (Early Llandovery) of northwestern New Brunswick. In A guidebook to the geology of northeastern Maine and neighboring New Brumswick. Edited by D.C. Roy and R.S. Naylor. 72nd Annual Meeting of the New England Intercollegiate Geological Conference, Boston College Press, pp. 202-211.

HÄNTZSCHEL, W. 1975. Trace fossils and problematica. In Treatise on invertebrate Paleontology, Part W. Miscellanea. Edited by C. Teichert. University of Kansas Press and Geological Society of America, Lawrence, KS, pp. W1-W296.

HAYWARD, B.W. 1976. Lower Miocene bathyal and submarine canyon ichnocoenoses from Northland, New Zealand. Lethaia, 9, pp. 149-162.

HEER, 0. 1865. Die Urwelt der Schweiz. Zurich, 622p.

HEEZEN, B.C. and HOLLISTER, C.D. 1971. The Face of the Deep. Oxford University Press Incorporated, 659p.

HEINBERG, C. 1973. The internal structure of the trace fossils Gyrochorte and Curvolithus. Lethaia, 6, pp.227238 .

HITCHCOCK, E. 1858. Ichnology of New England. A report on the sandstone of the Connecticut Valley, especially its footprints. W. White (Boston), 220p.

KEITH, B.D. and FRIEDMAN, G.M. 1977. A slope-fan-basin-plain model, Taconic sequence, New York and Vermont. Journal of Sedimentary Petrology, 47, pp. 1220-1241.

KSIAŻKIEWICZ, M. 1977. Trace fossils in the flysch of the Polish Carpathians. Palaeontologia Polonica 36, 208p.
McCABE, P.J. 1978. The Kinderscoutian Delta (Carboniferous) of Northern England: A Slope Influenced by Density Currents. In Sedimentation in Submarine Canyons, Fans, and Trenches. Edited by D.J. Stanley and G. Kelling. Dowden, Hutchinson and Ross Incorporated, pp. 116-126.

McCARTHY, B. 1979. Trace fossils from a Permian shoreface-foreshore environment, eastern Australia. Journal of Paleontology, 53, pp. 345-366.

MICHELAU, P. 1956. BeZorhaphe kochi (Ludwig 1869), eine Wurmspur im europäischen Karbon. Geologische Jahrbuch, 71, pp. 299-330.

MIDDLETON, G.V. and BOUMA, A.H., Editors. 1975. Turbidites and Deep-Water Sedimentation. Society of Economic Paleontologists and Mineralogists, Short Course, Anaheim, 157p.

OSGOOD, R.G. 1970. Trace fossils of the Cincinnati area. Paleontographica Americana, 5, pp. 282-444.

OSGOOD, R.G. and DRENNEN, W.T. 1975. Trilobite trace fossils from the Clinton Group (Silurian) of east-central New York State. Bulletins of American Paleontology, 67, pp. 299-348.

PICKERILL, R.K. 1980. Phanerozoic flysch trace fossil diversity - observations based on an Ordovician flysch ichnofauna from the Aroostook-Matapedia Carbonate Belt of northern New Brunswick. Canadian Journal of Earth Sciences, 17, pp. 1259-1270.

PICKERILL, R.K. and FORBES, W.H. 1979. Ichnology of the Trenton Group in the Quebec City area. Canadian Journal of Earth Sciences, 16, pp. 2022-2039.

RAST, N. and STRINGER, P. 1980. A geotraverse across a deformed Ordovician ophiolite and its Silurian cover, northern New Brunswick, Canada. Tectonophysics, 69, pp. 221-245.

RAST, N., and PICKERILL, R.K. In preparation. The Carys Mills Formation an example of fossil contourites. 
ROY, D.C. and MENCHER, E. 1976. Ordovician and Silurian stratigraphy of northeastern Aroostook County, Maine. In Contributions to the stratigraphy of New England. Edited by L.R. Page. Geological Society of America, Memoir 148, pp. 25-52.

SCOTT, R.M. and BIRDSALL, B.C. 1978. Physical and Biogenic Characteristics of Sediments from Hueneme Submarine Canyon, California Coast. In Sedimentation in Submarine Canyons, Fans, and Trenches. Edited by D.J. Stanley and G. Kelling. Dowden, Hutchinson and Ross Incorporated, pp. 51-64.

SEILACHER, A. 1959. Zur ökologischen Charakteristik von Flysch und Molasse. Ecologae Geologicae Helvetiae, 51, pp. 1062-1078.

1967. Bathymetry of trace fossils. Marine Geology, 5, pp. 413428.

1977. Pattern analysis of Paleodictyon and related trace fosfils. In Trace fossils 2. Edited by T.P. Crimes and J.C. Harper. Geological Journal Special Issue Number 9, Seel House Press, Liverpool, pp. 289334 .

1978. Use of trace fossil assemblages for recognizing depositional environments. In Trace Fossil Concepts. Edited by P.B. Basan. Society of Economic Paleontologists and Mineralogists, Short Course No. 5, pp. 185-201.

SEILACHER, A. and MEISCHNER, D. 1965. Fazies - Analyse im Paläozoikum des Oslo-Gebietes. Geologische Rundschau, 54, pp. 596-619.

SHEPARD, F.P. and DILL, R.F. 1966. Submarine canyons and other sea valleys. Chicago, Rand McNally and Company 381p.

SHEPARD, F.P., MARSHALL, N.F., McLOUGHLIN, P.A. and SUlLIVAN, G.G. 1979. Currents In Submarine Canyons and Other Seavalleys. American Association of Petroleum Geologists, Studies in Geology No. 8, 173p.
SIMPSON, S. 1957. On the trace fossil Chondrites. Quarterly Journal of the Geological Society of London, 112, pp. 475-499.

STANLEY, D.J. and BERTRAND, J.P. 1979. Submarine slope, fan and trench sedimentation - New concepts and problem solving. Penrose Conference Report, Geology, 7, pp. 49-52.

STANLEY, D.J. and KELLING, G., Editors. 1978. Sedimentation in Submarine Canyons, Fans, and Trenches. Dowden, Hutchinson and Ross Incorporated, 395p.

STANLEY, D.J., PALMER, H.D. and DILL, R.F. 1978. Coarse Sediment Transport by Mass Flow and Turbidity Current Processes and Downslope Transformations in Annot Sandstone Canyon - Fan Valley Systems. In Sedimentation in Submarine Canyons, Fans, and Trenches. Edited by D.J. Stanley and G. Kelling. Dowden, Hutchinson and Ross Incorporated, pp. 85-115.

STRINGER, P. and PICKERILL, R.K. 1980. Structure and sedimentology of SiluroDevonian between Edmundston and Grand Falls, New Brunswick. In A guidebook to the geology of northeastern Maine and neighboring New Brunswick. Edited by D.C. Roy and R.S. Naylor. 72nd Annual Meeting of the New England Intercollegiate Geological Con ference, Boston College Press, pp. 262-277.

TAYLOR, B.J. 1967. Trace fossils from the Fossil Bluff Series of Alexander Island. Bulletin of the British Antarctic Survey, 13, pp. 1-30.

TRUMBULL, J.V.A. and MCCAMIS, M.J. 1967. Geological exploration in an East Coast submarine canyon from a research submersible. Science, 158, pp. 370372 .

VALENT INE, P.C., UZMANN, J.R. and COOPER, R.A. 1980. Geology and biology of Oceanographer submarine canyon. Marine Geology, 38, pp. 283-312.

WALKER, R.G. 1975. Generalized facies models for resedimented conglomerates 
of turbidite association. Bulletin of the Geological Society of America, 86, pp. 737-748.

Revtewers: T.L. Harland W.H. Forbes J.B. Hamilton 